\title{
The Decline of Women in Russian Engineering Education
}

\section{Prof. Svetlana Vasilievna Barabanova, Kazan National Research Technological University}

Dr. Svetlana Barabanova was born in the U.S.S.R. and graduated with a Ph.D in Law from Kazan State University in 1983. In 1986, she started work at Kazan State Technological University, now known as Kazan National Research Technological University. Dr. Barabanova is a specialist in Educational Law and a participant in government commissions for perfection of educational legislation. She has also researched the different problems of engineering education for many years such as lack of educational training. Dr. Barabanova has one daughter and her hobbies include reading, traveling, and caring for her cat.

Dr. Phillip Albert Sanger, Purdue University, West Lafayette

Dr. Julia Ziyatdinova, Kazan National Research Technological University

Anastasia Sokolova, Kazan National Research Technological University

Dr. Vasiliy G. Ivanov, Kazan National Research Technological University 


\title{
The Decline of Women in Russian Engineering Education: Historical and Societal Forces at Play
}

\begin{abstract}
Since the Communist Revolution of 1917 and during the ensuring Soviet times, the role of women in engineering and engineering education was strong with almost $60 \%$ of the engineers being women. Since the fall of the Soviet Union, Russian women in these engineering careers has fallen to below $40 \%$ of the engineering workforce with a continuing downward trend. As a point of reference, the representation of women in the U.S. engineering workforce has remained around $9 \%$ with a very large attrition and departure of women from engineering professions during college and their early professional life.
\end{abstract}

For a long time, the gender factor did not have any impact on solving the Russian problems, either politically, economic, or social. The presence of women in the technical professions of an engineering university has a number of advantages while presenting many problems. Among the many problems are the following: (1) a lack of career advancement for women in engineering education; (2) a shortage of women in administrative positions with influence in the decision making process; (3) the resurgence of chauvinistic stereotypes for women; and (4) the conflict between family and professional life.

This paper explores the impact of gender bias in the Russian academic community and assesses the obstacles for technically trained women in the male dominated Russian university.

\section{Introduction}

Since 1917 and until the end of the Soviet era, the role of women was very important in the engineering and engineering education professions and this role steadily grew with almost 60 percent of all the engineers being women in the Soviet era. One of the main reasons for this significant role of women was a mass liberation of women from their "domestic slavery". A popular theme is exemplified by Vladimir Lenin's politically important slogan that claimed that "Even a kitchen maid can rule the state" in Russia. In that same era, though, a number of social, cultural, and political reason forces resulted in women not playing a key role in solving the problems of Russia. The modern demographic situation, the problems in engineering education and science backed up by statistical data suggest the need to take the influence of women into account when assessing the role of women in engineering and the health of the Russian system of education.

\section{Demographic Shift in Male to Female Population}

At many periods of Russian history there have been fewer men in Russia than women. Primary reasons for this include the high death rates in the two World Wars, the October Revolution, the war campaigns in Afghanistan and Chechnya, in addition to the high incidence of drug and alcohol addiction. After the second World War, demographers diligently tracked the difference 
in the birthrate between number of men and women. In the following forty years the rate of male births continued to increase. Since 1990, the trend has reversed and was accompanied an overall decrease in the Russian population. One of the main reasons for the reversal is the high mortality rate among the male population. This accelerated decrease in the male population was clearly pointed out by Kutchmayeva. ${ }^{i}$ In 2002, during the Russian population census, the difference between the number of women and men was 9,956,000 people. According to the 2010 census, there are 10,515,000 more women in Russia than men. In the age group 15-64, the male to female ratio was 0.92 . In the age group older than 65 , the ratio drops to 0.46 . As a point of reference, the corresponding ratio in the United States would be 0.995 and .75 while the U.S population continues to grow at a $0.75 \%$ annual rate. Several of the impacts of this sex imbalance are: 1) women are needed to fill the critical roles particularly in engineering and 2) women plays a stronger role in the family structure with a high proportion of single women families.

The Role of Woman in Manufacturing Industry and Science

During the Second World War women were working in the factories and heavy industries replacing men in all traditionally male-dominant manufacturing jobs. Different countries sought different solutions to this problem. In the USA and the UK, a number of campaigns was run to help women endure the weight of this burden, and gave birth to the famous poster that pictured a girl demonstrating her biceps and the slogan, "We Can Do It!" In Russia, the main slogan, "Everything for the front line, everything for the victory" was supported the women of all the countries in the anti-Hitler coalition with many military and logistical roles.

In the post soviet era the number of female engineers in Russian mechanical engineering dropped below $40 \%$, and this trend remains low. As a point of reference, women representation in the U.S. engineering workforce has remained around 9\%. Many women leave engineering industry while studying at college and in the beginning of their career.

In $1985,4.5 \%$ of the leadership roles in the manufacturing industry were held by female leaders versus $9 \%$ held by their male colleagues. During the perestroika in the 90 s, the process of displacement of women from the leadership positions and from the decision-making domain intensified. In period between 1985 and 2009, a total number of female leaders in all sectors decreased from $11 \%$ to $5.6 \%{ }^{1}$ An analysis of the changes that have occurred in the first decade of the $21^{\text {st }}$ century is provided in table 1 . Women practitioners in engineering decreased 30,000 while the social science and humanities increased measurably $(+5,000)$. Women represent $36.8 \%$ of the researchers in the engineering sciences, $41.6 \%$ in the natural sciences, $59.2 \%$, in the social sciences and $64 \%$ in the humanities. 
Table 1. The number of female workers in natural and engineering sciences is decreasing

\begin{tabular}{|l|l|l|l|l|l|l|l|}
\hline $\begin{array}{l}\text { 2002 year } \\
\text { 2011 year }\end{array}$ & Total & $\begin{array}{l}\text { Natural } \\
\text { sciences }\end{array}$ & $\begin{array}{l}\text { Engineering } \\
\text { sciences }\end{array}$ & $\begin{array}{l}\text { Social } \\
\text { sciences }\end{array}$ & Humanities & $\begin{array}{l}\text { Medical } \\
\text { sciences }\end{array}$ & $\begin{array}{l}\text { Agricultural } \\
\text { sciences }\end{array}$ \\
\hline Researcher & 187792 & 43785 & 114843 & 8219 & 4546 & 8778 & 7621 \\
& 155318 & 37303 & 83398 & 10044 & 7571 & 9921 & 7081 \\
\hline Doctor of & 4122 & 1768 & 225 & 293 & 604 & 1070 & 162 \\
science & 6707 & 2371 & 325 & 868 & 1049 & 1709 & 385 \\
\hline PhD & 28477 & 13999 & 4372 & 2097 & 1820 & 4014 & 2175 \\
& 33007 & 14269 & 3474 & 4562 & 3478 & 4604 & 2620 \\
\hline
\end{tabular}

Social Protection, Compensations, and Objective Reality

Within the context of this research, woman in the engineering and engineering education disciplines face the following problems: (1) the lack of career opportunities for women with engineering education; (2) an insignificant number of women on administrative positions with influence on the decision-making process; (3) the resurgence of female related stereotypes; and (4) the conflict between values of family and professional life.

One of the indicators of the democratic development of a society is the equality between men and women. Female emancipation is achieved in several different ways: 1) through the legal system and the acquisition of equal rights and opportunities with men; 2) through societal differentiation and learning how to protect their rights; 3) on an individual level through the realization of the true value of their personality and through the acquisition of social and communication skills.

In Russia, women are guaranteed the legal equality with men by the Constitution of the Russian Federation, the Labor Code and the Domestic Relations Code of the Russian Federation. At the same time, the law significantly relaxes labor and life conditions for women in comparison to men in a number of situations. Women in Russia are not subjected to the death penalty. A number of industries restrict the use of female labor. Women are guaranteed increased legal protection during their pregnancy and during the first 1.5 years of life of their child. Specific regulations determine female labor in rural areas. Women are eligible for a lower retirement age (they can retire five years earlier than men), and a reduced time in employment is needed to become eligible for the retirement pension ( 5 years less of the work record) .

However, there are issues that stand in the way of true societal equality between men and women in Russia. First, even though no one is surprised to see a female design-and-planning engineer or a female director of the metallurgical complex, such jobs generally don't come easy for women due to the their physiological and psycho-emotional. Certain professions simply weren't designed for them.

Secondly women do not choose the engineering profession due to a lack of confidence and belief that this career is right for them and they can become professionals in it. In addition they prefer a family role as their professional career. Studies suggest that the roots of such uncertainty can be found on early stages of professional study. The very social climate of the university can 
influence intentions of female students and make them doubt their career choice ${ }^{4,5}$. In a 2007 study, the sociologists interviewed 288 students who entered engineering schools to check whether their perception of their profession and life had changed. All these students followed similar courses and passed similar tests with female students often getting higher marks. However, according to the study, female students were less confident in their professional skills than their male colleagues and question whether the engineering profession is right for them. Such a lack of confidence leads to female students dropping the engineering courses and/or looking for a job in another career sector after graduation.

Third, researchers argue that there are small, but significant differences in how the male and female students are treated during their collegiate study. The majority see the engineering profession as traditionally male. This research has shown that, contrary to common belief, the desire to create a family is not the reason that female students drop their courses. No relationship has been found between their low estimate of their math skills and their unwillingness to develop their professional skills. The main reason is a doubt of female students in their ability to correspond to the role traditionally seen as male.

The engineering profession has historically been considered male dominated. A woman seeking a career in physics, engineering, or computer science even today even now will, at best, make equally men and women smile and at worst she will cause the distrust of the employer and will fail to get the job. Only 7 of managing directors will select a woman over a man where male and female applicants have equal competence. More than 40 percent believe that the number of women among the employed part of population will keep declining.

Meanwhile times have changed. Engineering careers used to be linked to work in factories and poor labor conditions. The workplace has dramatically changed with an improved factory environment and a more respectful factory floor workforce. The key requirements are a good mind and an excellent computer competency. The need for raw physical strength has given way to the need for orderliness and an ability to concentrate, both areas in which women excel. ${ }^{3}$ In coming years this trend will become more obvious. In a number of Russian families, men and women have already swapped their places. While women pursue their careers, men turn into stay-at-home dads.

\section{Gender reality}

An express-poll conducted at the Kazan National Research Technological University (KNRTU) in 2012 has shown that the Kazan female students doing traditional engineering courses are more educationally ambitious and more optimistic about their career prospects than their American colleagues. They have a genuine interest in their chosen profession, perform well in their studies and get higher marks in the engineering subjects. This is good and bad at the same time. The majority of the students, including the students of the engineering institutions, are female. After graduation they will have to work in male-dominated teams. A significant portion of the male workers may not accept women's abilities in the engineering profession. Some men will even see it as an attempt to occupy their own territory. As a consequence, the female workers will constantly have to prove themselves to university teachers to their ultimate bosses and other office workers. 
It is harder for female workers to climb the career ladder in the traditionally male professions where there is resistance to female supervisors. Women will have to show true grit. If a woman doesn't want to work with a furnace or operate the drilling rig, she will need to learn how to manage those who will do it.

Work in male-dominated Russian environment, however, can also become advantageous for women as a result of the male/female population imbalance. The possibility of finding a husband increases dramatically in a workplace with a high percentage of male workers. In Russia, especially in the remote regions, the number of the early student marriages is still higher than in the other developed countries. When a young woman fails to find a husband during her student years, the challenge of finding a suitable partner increased when she has entered the workforce. However work in a male-dominated team often represents opportunity for unmarried women. By comparison, a workplace with many female subordinates has not encouraged their male supervisors to be polite and look after themselves. The problem of sexual harassment by the supervisors stands more acute in female-dominated workplace environments.

The prognosis for the future?

In Russian engineering higher education, more than a half of all the workers are women and the institutional administration is traditionally male-dominant. For example in Kazan, where eastern traditions add an additional gender factor, academic administration is dominated by men: only two of the eleven members of the administrative body (rector and vice-rectors) of the Kazan National Research Technological University are women. The Rectorate of the Kazan Federal University includes eleven men and only one woman. The Rectorate of the Kazan State University of Architecture and Engineering has six men and one woman in leadership positions. All eight members of the administration of the Kazan National Research Technical University are men. Only Almetyevsk State Oil University has gender equality in the administration with four men and four women when deputy vice-rectors are included in the count. Moving down the administrative ladder, the situation improves but the imbalance remains. Women with degrees in humanities, with few exceptions, have even less chances to take the leadership positions. Thus major shifts are unlikely in the role of women in the technical academic professions or in the content of education.

This problem is an acute one and a relatively new problem on the agenda of modern engineering education and science in Russia. Meanwhile securing gender equality in the engineering and engineering education sector may help to improve the quality of engineering education.

Bibliography

[1] URL: http://baltinfo.ru/2011/03/28/pervye-itogi-perepisi-vlasti-ne-v-silakh-ostanovit-vymiranie-195677

[2] The science of Russia in figures: statistical compilation. M.: CSRS, 2012.

[3] Yu.G.Volkov, VI Dobrenkov, VN Nechipurenko AV Popov. Sociology: Edition 3d. M.: 2008. P. 288.

[4] URL:http://kinglena.com/content/blondinka-na-zavode-zhenshchiny-i\%C2\%ABmuzhskie\%C2\%BB-professii

[5] V. Nikonorov. Why women are not given male professions URL:

http://www.utro.ru/articles/2011/10/26/1007062.shtml 


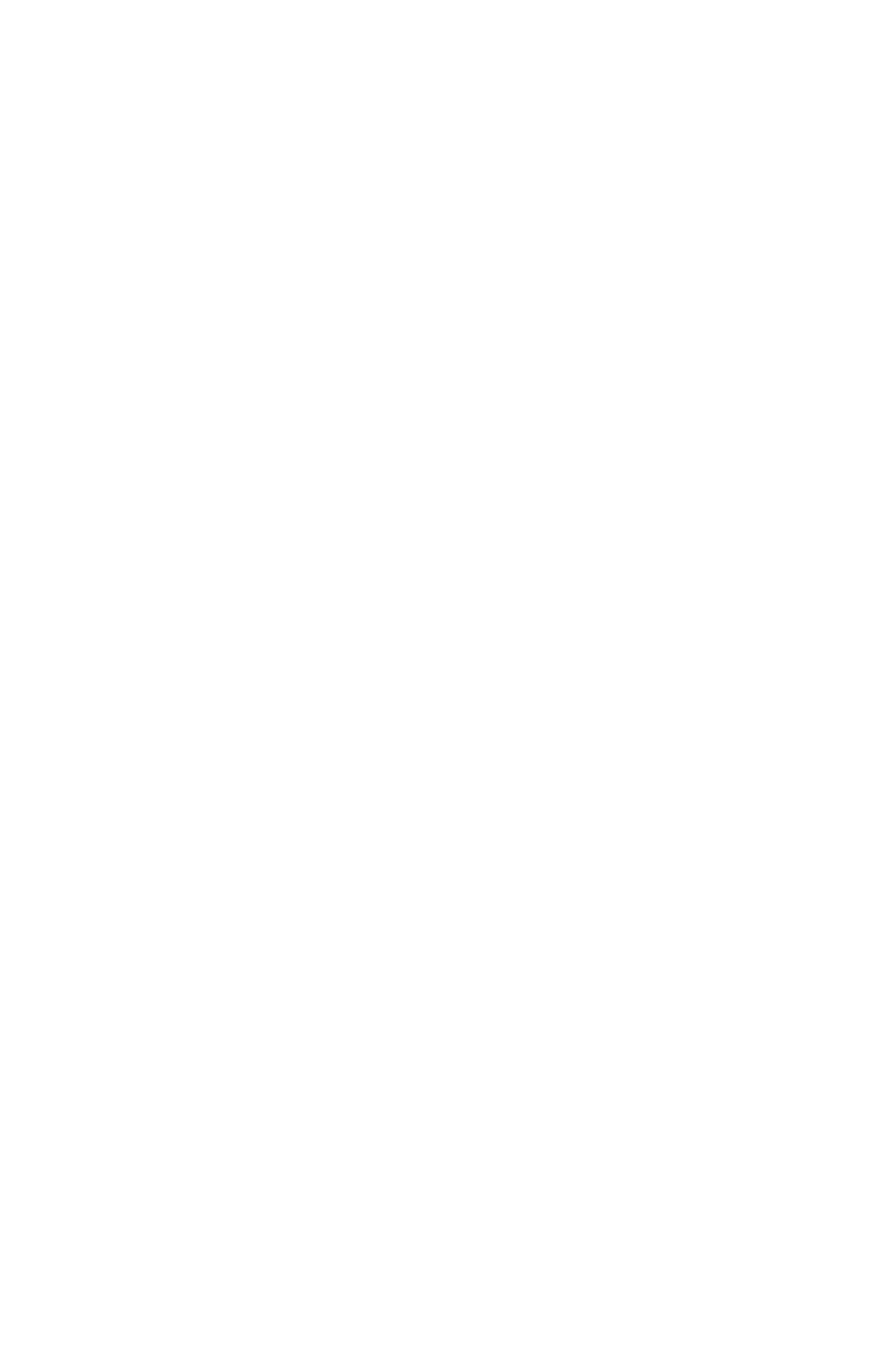

(1)

ه్

N

$\omega$

$\vec{v}$

V 